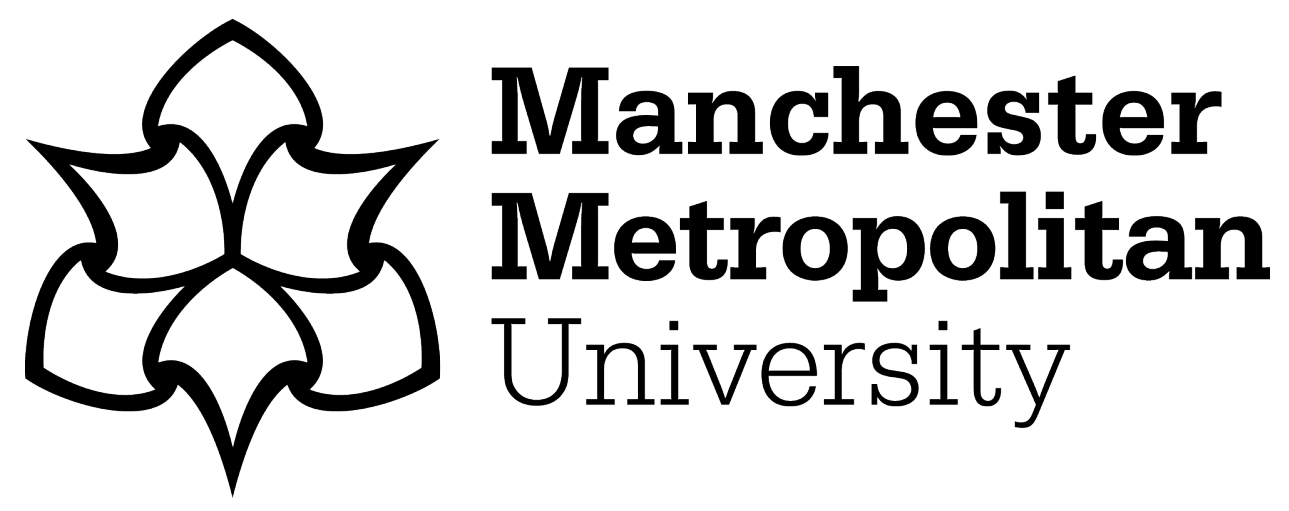

Giladi, P (2017) Moving from Transcendental Logic to Dialectical Logic. Hegel-Jahrbuch, 2016 (1). pp. 394-397. ISSN 0073-1579

Downloaded from: https://e-space.mmu.ac.uk/621008/

Publisher: de Gruyter

DOI: https://doi.org/10.1515/hgjb-2016-0166

Please cite the published version 


\section{Moving from Transcendental Logic to Dialectical Logic}

This paper is concerned with how best to explicate the connection between Kant's transcendental logic and Hegel's dialectical logic. After very briefly detailing Robert Pippin's influential account of the Kant-Hegel relationship, I offer a basic criticism of his transcendentalist interpretation of Hegel. I argue that while this works well against Pippin's reading, there is still space to regard Hegel as doing transcendental philosophy. What is crucial here is that Hegel's rejection of transcendental idealism does not obviously rule out the possibility of Hegel being bound to transcendental philosophy itself. I proceed to show how this is possible, by differentiating the project of transcendental argumentation and the project of making transcendental claims. I argue that Hegel endorsed the latter project and not the former project. I go on to claim that one can regard Hegel's argument for an immanent conception of infinity, and his use of Spinoza's 'All Determination is Negation' principle as legitimate examples of Hegel doing transcendental philosophy in a non-orthodox Kantian manner. To put my point bluntly, Hegel is a transcendental philosopher to the extent that he is committed to identifying transcendental claims - this does not commit him to either transcendental argumentation or working within Kant's constraints. If this is a more compelling interpretation of the Kant-Hegel relationship than the Pippinian school of thought, then it seems we can cash out the positive relationship between Kant and Hegel in a more nuanced manner.

Robert Pippin has argued that Hegel's idealism should be seen as squarely following Kant's shift from pre-Critical metaphysics to critical metaphysics. This idea involves two fundamental claims, one positive, and one negative. The latter effectively amounts to viewing Hegel as sharing Kant's proto-Strawsonian attitude to the fruitlessness of traditional metaphysical speculation concerning substance, God, etc. As Pippin writes, "thereafter, instead of an a priori science of substance, a science of 'how the world must be' ... a putative philosophical science was directed to the topic of how any subject must 'for itself' take or construe or judge the world to be". ${ }^{1}$ What he means by this is that Kant wished to initiate a change in the direction of enquiry, by asking us to focus on the necessary conditions required for the possibility of experience of the world as a self-conscious discursive subject, rather than determine the necessary structure of the world itself. Such a change in the direction of

\footnotetext{
${ }^{1}$ R. B. Pippin, 1990: 839.
} 
enquiry is brought about the development of transcendental logic, a logic which aims to illustrate how conceptual contraries are necessarily bound up and interdependent. One can take, to use just one example from Kant's texts, the argument of the Refutation of Idealism as a locus classicus of transcendental logic. ${ }^{2}$

According to Pippin, one should see Hegel as continuing and extending this transcendental turn in philosophy. For example, Pippin stresses how enamoured Hegel was by Kant's transcendental discovery of the apperceptive nature of experience. As Hegel writes in the Logic and in the Berlin Phenomenology:

It is one of the profoundest and truest insights to be found in the Critique of Pure Reason that the unity which constitutes the nature of the Notion is recognised as the original synthetic unity of apperception, as the unity of the $I$ think, or of selfconsciousness. (Science of Logic: 584)

There can be no consciousness without self-consciousness. I know something, and that about which I know something I have in the certainty of myself otherwise I would know nothing of it; the object is my object, it is other and at the same time mine, and in this latter respect I am self-relating. (Berlin Phenomenology: 55)

However, a basic problem with Pippin's account - at least with how it is expressed in Hegel's Idealism - is that, to quote Brady Bowman, "post Kant is not necessarily propter Kant". ${ }^{3}$ In other words, Bowman's Hegel is not the Hegel of the Pippin school of thought: Hegel is not a transcendentalist who merely carries through transcendental idealism. Of course, though, Hegel's status as a post-Kantian thinker does not necessarily mean he is fundamentally opposed to or anti Kant. One can be someone's successor without necessarily following one's predecessor: Hegel, in many important ways, differs from Kant, but at the same time, he is indebted to the great philosopher. What I now hope to explain in more detail now is how exactly my account is supposed to work - how exactly I understand the relationship between transcendental logic and dialectical (speculative) logic. My general suggestion here will be that Hegel takes some of the transcendental insights that were available to Kant, but rather than articulating them within the (to Hegel) restricted compass of transcendental idealism, he deploys them within the more metaphysically rich outlook of his objective idealism, in a way that both builds on Kant's approach, but also fundamentally transforms it. I take the following quote from Bowman to be sympathetic to this approach: "Speculative philosophy is

\footnotetext{
${ }^{2}$ Cf. B275-6 of the Critique of Pure Reason.

${ }^{3}$ B. Bowman, 2013: 3 .
} 
a systematic critique and overcoming of traditional ontological (categorial) thought in service of an alternative, revisionary metaphysics". ${ }^{4}$ Furthermore, what we shall find to be of paramount significance in Hegel's development of dialectical logic is how he makes transcendental claims independently of the project of transcendental argumentation. By a 'transcendental claim', I mean a proposition which states that $y$ is a necessary condition for the possibility of $x$. By 'the project of transcendental argumentation', I mean the practice of using transcendental claims for the purposes of defeating various sceptical positions.

To understand the movement from transcendental logic to dialectical logic, it will help to consider Hegel's argument for an immanent conception of infinity, and his use of the Spinozist principle 'All Determination Is Negation'. Let us first begin with Hegel's reflections on the nature of the infinite:

[It is said that] the infinite, one the one side, exits by itself, and that the finite which has gone forth from it into a separate existence ...; but it should rather be said that this separation is incomprehensible ... But equally it must be said that they are comprehensible, to grasp them even as they are in ordinary conception, to see that in the one there lies the determination of the other ... is to see the simple insight into their inseparability ... This unity of the finite and infinite and the distinction between them are just as inseparable as are finitude and infinity. (Science of Logic: 153-154)

From the above passage, we can construct the following argument:

(1) If the finite is separate from the infinite, then there is something outside of the infinite.

(2) There is nothing outside of the infinite.

(3) Therefore, the finite is not separate from the infinite.

As we can see from my formulation of Hegel's argument, his argument is one which has neither the dialectical function of a transcendental argument nor the logical structure of a transcendental argument. For, Hegel is concerned with dismissing the claims of pre-Kantian rationalists as metaphysical conjecture, since if the infinite were understood in opposition to the finite, then the infinite would be finite itself, because it would be limited by the finite. "There would then be per impossibile a greater reality than the infinite. Hence, the true infinite must therefore include the finite". 5 I think, given Hegel's concern with establishing

\footnotetext{
${ }^{4}$ B. Bowman, 2013: 7.

${ }^{5}$ F. C. Beiser, 2005: 142.
} 
the necessary conditions for the possibility of the infinite being the infinite, that there is very good reason to regard his argument as aiming to make a metaphysical transcendental claim. He can be judged as Kant's successor, not because Hegel merely takes up Kant's mantle by focusing on the necessary conditions for the possibility of experience/cognition, pace Pippin, but because Hegel seeks to build on the discoveries Kant made about interdependency by underlining how infinity and finitude are necessarily bound up together for their existence but where Kant saw such dependencies in merely conceptual terms, Hegel treats them ontologically. This is why Hegel regarded his absolute/objective idealism as improving upon Kant's psychological/subjective idealism: for Kant's most serious error was falling into the pitfalls of various dualisms, despite possessing correct transcendental insights into the nature of interdependency, whereas Hegel's absolute idealism - which is famous in part for its systematic rejection of those dualisms - aims to preserve Kant's great discoveries whilst at the same time taking them further, by treating them as metaphysical claims in a way that Kant himself has refused to do. What this shows, therefore, is that "... Hegel's [dialectical] Logic is literally nourished by Hegel's discussion of transcendental philosophy ..."6 and Hegel's logic transforms transcendental logic.

The conception of infinity on Hegel's account is a crucial part of his dialectical logic. Another crucial part of that logic is Hegel's use of the principle 'All Determination Is Negation'. ${ }^{7}$ For Hegel, the negation that accompanies determination is a necessary condition for the possibility of being in a meaningful sense. In other words, Hegel claims that if something is to count as being, then it must have determination and so negation. ${ }^{8}$ His

\footnotetext{
${ }^{6}$ B. Longuenesse, 2007: 16

${ }^{7}$ Cf. Science of Logic: 113, 536; and Encyclopaedia Logic: $§ 87 Z, \S 91 Z$.

${ }^{8}$ Robert Stern (forthcoming) notes that the way Hegel understands the 'All Determination Is Negation' principle seems to be the opposite of the way in which Spinoza himself understands it. For Spinoza, the negation that comes with determination is a privation of being - cf. his letter to Jelles of 1674:
}

\begin{abstract}
With regard to the statement that figure is a negation and not anything positive, it is obvious that matter in its totality, considered without limitation [indefinitè consideratam], can have no figure, and that figure applies only to finite and determinate bodies. For he who says that he apprehends a figure, thereby means to indicate simply this, that he apprehends a determinate thing and the manner of its determination. This determination therefore does not pertain to the thing in regard to its being; on the contrary, it is its non-being. So since figure is nothing but determination, and determination is negation [Quia ergo figura non aliud, quam determinatio, et determinatio negatio est], figure can be nothing other than negation, as has been said.
\end{abstract}

Jacobi also notes that the 'all determination is negation' principle is meant to indicate a privation of being:

Determinatio est negatio, seu determinatio ad rem juxta suum esse non pertinent [Determination is negation, i.e. determination does not pertain to a thing according to its being]. Individual things therefore, so far as they only exist in a certain determinate mode, are non-entia; the indeterminate infinite being is the one single true ens reale, hoc est, est omne esse, \& praeter quod nullum datur est [this is the real being; it is the all of being, and apart from it there is no being]. (Concerning the Doctrine of Spinoza: 219-20) 
argument can be understood as follows: for something to be more than just a completely formal and abstract pure being, which for Hegel is more or less the same as nothingness, there must be some kind of determination. Such determination must involve some negation. As Robert Stern writes, “the principle thus plays an important role within Hegel's ontological position, where it is crucial to his case against Parmenidean monism, which treats reality as a 'one', lacking in any element of difference; rather, Hegel argues, reality must incorporate some element of differentiation, of distinctions within being, where without these 'negations' it would not comprise determinate being, but would be no more than the nothingness of pure being". " Now, there seems to be good reason to interpret Hegel's use of the 'All Determination Is Negation' principle to be a transcendental claim: in the previous case of infinity, Hegel's concern was to show the necessary ontological conditions for the infinite being the infinite; here, Hegel is interested in establishing the necessary conditions for being as being proper. Therefore, this is another instance of a transcendental claim being made independently of the project of transcendental argumentation. Not only that, though, we can see from these two examples in Hegel's logico-metaphysical writings one way of understanding Bowman's claim that Hegel aims to derive from Kant a "completely altered view of logic". ${ }^{10}$ Logic, on the Hegelian model, is now cast as speculative and that the task of establishing interdependencies between conceptual contraries appears to have been extended to establishing ontological interdependency.

I take my position to share much in common with Sally Sedgwick's, who takes Hegel's critique of Kant to be a critical development of absolute idealism and speculative logic partly from Kantian transcendentalism. As she writes, "Hegel hopes to derive from certain Kantian doctrines specific clues to a superior form of idealism, an idealism which better captures the nature of human cognition and its exact abilities, as well as the relation between our cognition and objects". The movement from transcendental logic to dialectical logic, therefore, ultimately refers to the organic development of speculative logico-metaphysics from Kant's transcendental framework. Such an account of the relationship between Kant and Hegel preserves a degree of hostility between the two yet simultaneously insists on how much Hegel's speculative logic and metaphysics is indebted to Kant. Not only is post Kant not propter Kant, it may also not be too outlandish to think that post Kant is rather Hegelian.

\footnotetext{
${ }^{9} \mathrm{R}$. Stern, forthcoming: 2 - page numbers referred to in manuscript.

${ }^{10}$ Bowman, 2013: 9.
} 
Dr. Paul Giladi,

Department of Philosophy,

University of Sheffield, 45 Victoria Street,

Sheffield, S3 7QB, UK

paul.giladi@gmail.com 


\section{References}

F. C. BEISER. Hegel. New York \& London: Routledge, 2005.

B. BOWMAN. Hegel and the Metaphysics of Absolute Negativity. Cambridge: Cambridge University Press, 2013.

G. W. F. HEGEL. Science of Logic. A. V. Miller (trans.) London: Allen and Unwin, 1969.

--- The Berlin Phenomenology. M. J. Petry (trans.) Dordrecht: Riedel, 1981.

--- The Encyclopaedia Logic: Part I of the Encyclopaedia of the Philosophical Sciences with the Zusätze. T. F. Geraets, W. A. Suchting, and H. S. Harris (trans.) Indianapolis/Cambridge: Hackett Publishing Company, Inc., 1991.

--- Lectures on the History of Philosophy. E. S. Haldane (trans.) Lincoln: University of Nebraska Press, 1995.

I. KANT. Critique of Pure Reason. P. Guyer \& A. W. Wood (trans.) Cambridge: Cambridge University Press, 1998.

F. H. JACOBI. The Main Philosophical Writings and the Novel 'Allwill'. G. di Giovanni (trans.) \& (ed.) Montreal/Kingston: McGill-Queen's University Press, 1994.

B. LONGUENESSE. Hegel's Critique of Metaphysics. N. Simek (trans.) Cambridge: Cambridge University Press, 2007.

R. B. PIPPIN. Hegel's Idealism: The Satisfactions of Self-Consciousness. Cambridge: Cambridge University Press, 1989.

--- "Hegel and Category Theory", in: Review of Metaphysics 43 (1990), 839-848.

Robert STERN forthcoming. "Determination is Negation: The Adventures of a Doctrine from Spinoza to Hegel to the British Idealists”, in: Hegel Bulletin. 